\title{
FAKTOR-FAKTOR YANG BERHUBUNGAN DENGAN RISIKO TINGGI OBSTRUCTIVE SLEEP APNEA PADA PASIEN FIBRILASI ATRIUM
}

\author{
FACTORS THAT INFLUENCE HIGH RISK FOR OBSTRUCTIVE SLEEP APNEA \\ IN ATRIAL FIBRILLATION PATIENTS \\ Nushrotul Lailiyya, * Sobaryati, * Novia Aiko, * Chaerul Achmad**
}

\section{ABSTRACT}

Introduction: Atrial fibrillation $(A F)$ is the most frequent cardiac arrhythmia in the world and associated with high morbidity and mortality. Obstructive sleep apnea (OSA) is strongly associated with AF and its prevalence is $32 \%-62 \%$. Obstructive sleep apnea screening and its reduction are one approach to reduce the risk of and increasing the treatment effectiveness of $A F$.

Aims: To determine factors that influence the high risk for OSA in AF patients.

Methods: We performed a cross-sectional analytical and observational study in AF patients at Hasan Sadikin Hospital, Salamun Hospital, and Ujung Berung Hospital, Bandung during period of November 2017 to January 2018. STOPBANG were used to screen OSA.

Results: There were 100 subjects with age $62 \pm 12$ years old, 43\% male, 38\% smoking, 14\% obese, 16\% had neck circumference $\geq 40 \mathrm{~cm}$, and majority had high risk of OSA (71\%) and hypertension (74\%). The factors that influence the high risk for OSA in the AF patients were hypertension, age, gender, neck circumference, and smoking.

Discussion: Hypertension, age, gender, neck circumference, and smoking are related to the the high risk for OSA in AF patients.

Keywords: Atrial fibrillation, obstructive sleep apnea, STOPBANG

\section{ABSTRAK}

Pendahuluan: Fibrilasi atrium (FA) merupakan gangguan irama jantung (aritmia) yang paling banyak ditemukan di dunia dan berkaitan dengan morbiditas dan mortalitas yang cukup tinggi. Obstructive sleep apnea (OSA) sangat berkaitan dengan FA dengan prevalensi 32\%-62\%. Skrining OSA dan berhasilnya terapi OSA pada pasien FA merupakan salah satu pendekatan untuk menurunkan risiko dan meningkatkan efektivitas tata laksana FA.

Tujuan: Mengetahui faktor yang berhubungan dengan risiko tinggi OSA pada pasien FA.

Metode: Penelitian analitik observasional dengan studi potong lintang pada pasien FA di Poliklinik Kardiologi RSUP Dr. Hasan Sadikin, RS Salamun, dan RS Ujung Berung, Bandung selama periode November 2017-Januari 2018. Skrining OSA menggunakan kuesioner STOPBANG.

Hasil: Terdapat 100 orang subjek dengan rerata usia $62 \pm 12$ tahun, 43\% laki-laki, 38\% merokok, 14\% obesitas, $16 \%$ memiliki lingkar leher $\geq 40 \mathrm{~cm}$, serta mayoritas berisiko tinggi OSA (71\%) dan hipertensi (74\%). Faktor-faktor yang memengaruhi risiko tinggi OSA penelitian secara berurutan adalah hipertensi, usia, jenis kelamin, lingkar leher, dan merokok.

Diskusi: Hipertensi, usia, jenis kelamin, lingkar leher, dan merokok berpengaruh terhadap risiko tinggi OSA pada pasien FA.

Kata kunci: Fibrilasi atrium, obstructive sleep apnea, STOPBANG

*Departemen Neurologi FK Universitas Padjadjaran/RSUP Dr. Hasan Sadikin, Bandung; **Departemen Kardiologi FK Universitas Padjadjaran/RSUP Dr. Hasan Sadikin, Bandung. Korespondensi: noviaaiko@yahoo.com.

\section{PENDAHULUAN}

Fibrilasi atrium (FA) merupakan gangguan irama jantung (aritmia) yang paling banyak ditemukan di dunia, ${ }^{1}$ sekitar $1-4 \%$ pada populasi umum. Gangguan ini lebih sering terjadi pada usia tua atau dewasa, namun dapat juga terjadi pada usia muda. ${ }^{2-3}$ Data studi observasional multinational monitoring of trend and determinat in cardiovascular disease (MONICA) pada populasi urban di Jakarta mendapatkan angka kejadian FA sebesar $0,2 \%$ dengan rasio laki-laki dan perempuan 3:2. Populasi usia lanjut di Indonesia berdasarkan estimasi World Health Organization (WHO) akan bertambah, sehingga meningkatkan kejadian FA secara signifikan. Fibrilasi atrium menyebabkan peningkatan mortalitas dan morbiditas, termasuk stroke dan gagal jantung, serta penurunan kualitas hidup dan peningkatan beban ekonomi. ${ }^{3-5}$ 
Adanya FA juga menyebabkan terjadinya obstructive sleep apnea (OSA) hingga 32\% menurut Porthan dkk. ${ }^{6}$ Stevenson dkk mendapatkan nilai apnea hypopneu index (AHI) $>15$ pada kelompok pasien FA sebesar $62 \%$. Fibrilasi atrium berperan pada terjadinya OSA melalui proses peningkatan tonus vagal yang mengakibatkan meningkatnya aktivitas parasimpatis, sehingga resistensi saluran napas meningkat dan menurunkan tonus otot dilator faring yang selanjutnya menyebabkan kolaps faring. ${ }^{7-9}$ Skrining OSA dan berhasilnya terapi OSA pada pasien FA merupakan salah satu pendekatan untuk menurunkan risiko dan meningkatkan efektifitas tata laksana FA. ${ }^{6,10}$

Obstructive sleep apnea merupakan gangguan tidur yang sering dijumpai berkaitan dengan gangguan napas, yang disebut sleep breathing disorders (SBD). Prevalensinya sekitar 5\% dari populasi atau sekitar 15 juta orang dewasa Amerika dan berkaitan dengan peningkatan risiko penyakit kardiovaskular. ${ }^{11}$ Penelitian Gunawan di Jakarta pada 202 subjek berusia 35-73 tahun didapatkan prevalensi risiko tinggi OSA adalah 49,5\% yang mayoritas laki-laki (70\%). ${ }^{12}$

Obstructive sleep apnea juga berhubungan dengan obesitas dan secara independen meningkatkan risiko FA. ${ }^{13}$ Prevalensi OSA pada populasi usia pertengahan (30-60 tahun) adalah 4\% laki-laki dan $2 \%$ perempuan. Prevalensi ini meningkat secara dramatis seiring dengan pertambahan usia dan indeks massa tubuh (IMT).$^{14}$ Selama proses OSA terjadi hipoksemia dan hiperkapnia serta aktivasi simpatis yang menyebabkan terjadinya hipertensi. ${ }^{15-16}$

Faktor lain yang juga berhubungan dengan OSA adalah merokok, karena dapat menyebabkan inflamasi jalan napas dan kerusakan akibat asap rokok hingga mengubah fungsi mekanis, kemudian meningkatkan kolaps jalan napas selama tidur. ${ }^{17}$ Saat ini, salah satu metode skrining OSA adalah kuesioner STOPBANG yang memiliki sensitivitas dan spesifitas yang cukup tinggi dibandingkan dengan kuesioner skrining lainnya, serta mudah dilakukan. ${ }^{18}$

\section{TUJUAN}

Mengetahui faktor-faktor yang memengaruhi risiko tinggi OSA pada pasien FA.

\section{METODE}

Penelitian potong lintang terhadap pasien FA yang datang ke Poliklinik Kardiologi RSUP Dr. Hasan Sadikin, RS Salamun, dan RS Ujung Berung, Bandung, periode November 2017 hingga Januari

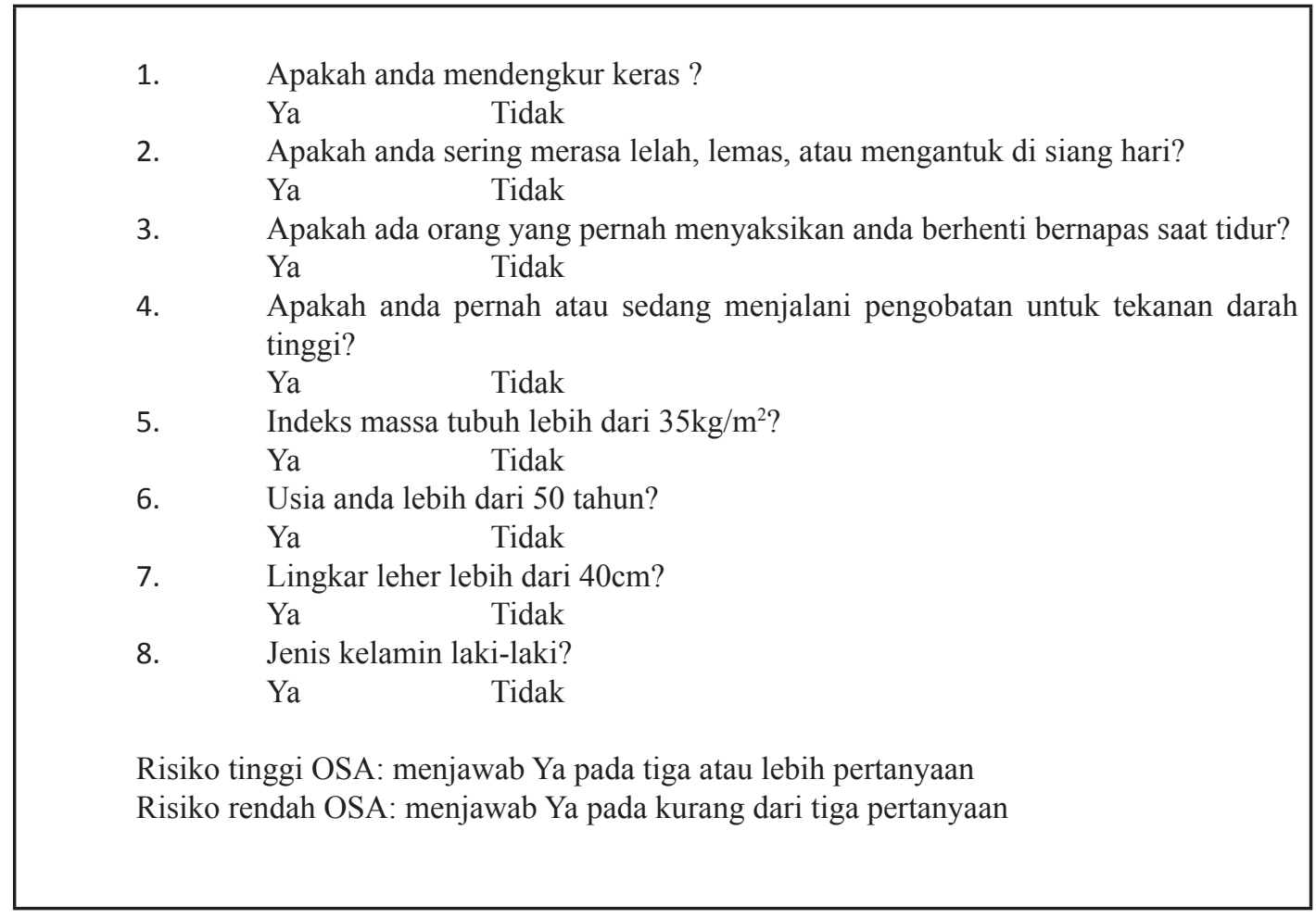

Gambar 1. Kuesioner STOPBANG Versi Bahasa Indonesia ${ }^{12}$ 
2018. Kriteria inklusi adalah pasien berusia $\geq 18$ tahun yang telah didiagnosis FA oleh dokter spesialis jantung berdasarkan hasil eletrokardiografi dan ekhokardiografi. Kriteria eksklusi adalah pasien FA dengan asma atau penyakit paru obstruktif kronik (PPOK), diabetes melitus (DM) tipe II, hipotiroid, gagal jantung kongestif New York Heart Association (NYHA) kelas 3 dan 4, penyakit jantung iskemik, penyakit jantung rematik, hamil, dan riwayat stroke.

Penilaian OSA berdasarkan kuesioner STOPBANG yang sudah diterjemahkan ke dalam Bahasa Indonesia (Gambar 1). ${ }^{12}$ Pasien dikelompokkan sebagai risiko tinggi OSA: bila menjawab Ya pada tiga atau lebih pertanyaan dan risiko rendah OSA: menjawab Ya pada kurang dari tiga pertanyaan. ${ }^{18}$

Subjek dilakukan pemeriksaan fisik dasar serta lingkar leher. Subjek dinyatakan hipertensi bila tekanan darah sistolik $\geq 140 \mathrm{mmHg}$ dan sistolik $\geq 90 \mathrm{mmHg}$, atau dalam terapi hipertensi. ${ }^{19}$ Penilaian obesitas berdasarkan IMT menurut WHO, yaitu $\geq 30 \mathrm{~kg} / \mathrm{m}^{2} .{ }^{20}$ Pengukuran lingkar leher dengan pita ukur melewati tepat di bawah kartilago tiroid dan tegak lurus terhadap sumbu panjang leher, subjek diminta melihat lurus ke depan dengan kedua bahu rileks. Lingkar leher dikatakan normal bila $<40 \mathrm{~cm} .{ }^{21}$

Usia dikategorikan menjadi $\geq 60$ tahun dan $<60$ tahun berdasarkan cut off batasan usia tua oleh WHO. ${ }^{22}$ Status merokok subjek dikelompokkan menjadi bukan perokok, perokok, dan bekas perokok. Bukan perokok adalah orang yang tidak pernah merokok atau merokok $<100$ batang selama hidupnya; perokok adalah orang yang merokok $>100$ batang sepanjang hidupnya dan saat ini masih merokok; sedangkan bekas perokok adalah orang yang merokok $>100$ batang sepanjang hidupnya dan telah berhenti pada saat ini. ${ }^{23}$

Penelitian ini telah mendapatkan persetujuan etik No. LB.04.01/A05/EC/209/VII/2018 dengan amandemen protokol dari ethical approval No. LB.04.01/A05/EC/338/XI/2017 pada tanggal 22 November 2017. Untuk melihat adanya pengaruh faktor-faktor risiko OSA digunakan analisis bivariat uji Chi-square atau Fisher Exact, dilanjutkan analisis multivariat kategorik (regresi logistik) dengan nilai prevalensi rasio (PR). Kriteria kemaknaan yang digunakan nilai $\mathrm{p}<0,05$. Adanya independensi atau tidak ada multikolinieritas antar variabel independen dilakukan analisis uji independensi/Collinearity.

\section{HASIL}

Didapatkan 100 subjek penelitian (Tabel 1) dengan rerata usia $62 \pm 12$ tahun, proporsi laki-laki $43 \%$, dan median lama menderita FA 36 bulan. Sebagian besar subjek menderita hipertensi (74\%), berisiko tinggi OSA (71\%), dan memiliki IMT normal (46\%).

Tabel 1. Karakteristik Subjek Penelitian $(n=100)$

\begin{tabular}{|c|c|c|}
\hline Karakteristik & n (\%) & Rerata \pm SD \\
\hline Usia (tahun) & & $62 \pm 12$ \\
\hline \multicolumn{3}{|l|}{ Kategori usia } \\
\hline - $\quad \geq 60$ Tahun & $53(53)$ & \\
\hline - $<60$ Tahun & $47(47)$ & \\
\hline \multicolumn{3}{|l|}{ Jenis kelamin } \\
\hline - Laki-laki & $43(43)$ & \\
\hline - Perempuan & $57(57)$ & \\
\hline \multicolumn{3}{|l|}{ Status merokok } \\
\hline - Tidak merokok & $61(61)$ & \\
\hline - Merokok & $5(5)$ & \\
\hline - Bekas perokok & $34(34)$ & \\
\hline \multicolumn{3}{|l|}{ Indeks massa tubuh $\left(\mathrm{kg} / \mathrm{m}^{2}\right)$} \\
\hline - Kurus & $14(14)$ & \\
\hline - Normal & $46(46)$ & \\
\hline - Gemuk & $26(26)$ & \\
\hline - Obesitas & $14(14)$ & \\
\hline Lama menderita FA (bulan) & & $36(0-360)$ \\
\hline \multicolumn{3}{|l|}{ Lingkar leher (cm) } \\
\hline - Tidak normal & $16(16)$ & \\
\hline - Normal & $84(84)$ & \\
\hline \multicolumn{3}{|l|}{ Hipertensi } \\
\hline - $\mathrm{Ya}$ & $74(74)$ & \\
\hline - Tidak & $26(26)$ & \\
\hline \multicolumn{3}{|l|}{ Risiko tinggi OSA } \\
\hline - Risiko rendah & $29(29)$ & \\
\hline - Risiko tinggi & $71(71)$ & \\
\hline
\end{tabular}

FA: fibrilasi atrium; OSA: obstructive sleep apnea; SD: standar deviasi.

Analisis bivariat (Tabel 2) menunjukkan usia $\geq 60$ tahun, laki-laki, merokok, lingkar leher tidak normal, dan hipertensi mempunyai pengaruh terhadap risiko tinggi OSA $(p<0,05)$. 
Tabel 2. Pengaruh Karakteristik Subjek dengan Risiko Tinggi OSA $(n=100)$

\begin{tabular}{|c|c|c|c|}
\hline \multirow{3}{*}{ Karakteristik } & \multirow{3}{*}{$\mathbf{n}$} & Risiko Tingg & \multirow{3}{*}{$\mathbf{p}$} \\
\hline & & OSA & \\
\hline & & $n=71$ & \\
\hline \multicolumn{4}{|l|}{ Kategori usia } \\
\hline - $\geq 60$ Tahun & 53 & $48(90,6)$ & $<0,001 *$ \\
\hline - $<60$ Tahun & 47 & $23(48,9)$ & \\
\hline \multicolumn{4}{|l|}{ Jenis kelamin } \\
\hline - Laki-laki & 43 & $37(86,0)$ & $0,004 *$ \\
\hline - Perempuan & 57 & $34(59,6)$ & \\
\hline \multicolumn{4}{|l|}{ Status merokok } \\
\hline - Merokok & 39 & $33(84,6)$ & $0,016 *$ \\
\hline - Tidak merokok & 61 & $38(62,3)$ & \\
\hline \multicolumn{4}{|l|}{ Obesitas $\left(\mathrm{kg} / \mathrm{m}^{2}\right)$} \\
\hline - Obesitas & 14 & $10(71,4)$ & 0,621 \\
\hline - Non obesitas & 86 & $65(75,6)$ & \\
\hline \multicolumn{4}{|l|}{ Lingkar leher } \\
\hline - Tidak Normal & 16 & $15(93,8)$ & $0,034 *$ \\
\hline - Normal & 84 & $56(66,7)$ & \\
\hline \multicolumn{4}{|l|}{ Hipertensi } \\
\hline - $\mathrm{Ya}$ & 74 & $62(83,8)$ & $<0,001 *$ \\
\hline - $\quad$ Tidak & 26 & $9(34,6)$ & \\
\hline
\end{tabular}

*Uji Chi-square atau Fisher Exact; IMT: indeks massa tubuh; OSA: obstructive sleep apnea; FA: fibrilasi atrium.

Tabel 3. Prevalensi Usia, Jenis Kelamin, Status Merokok, Obesitas, dan Hipertensi dengan Risiko Tinggi OSA $(n=100)$

\begin{tabular}{lccc}
\hline \multicolumn{1}{c}{ Variabel } & $\begin{array}{c}\text { Prevalensi } \\
\text { Ratio (PR) }\end{array}$ & IK 95\% & p \\
\hline $\begin{array}{l}\text { Usia ( } \geq 60 \text { tahun) } \\
\text { Jenis kelamin } \\
\text { (laki-laki) }\end{array}$ & 1,85 & $1,365-2,510$ & $<0,001^{*}$ \\
$\begin{array}{l}\text { Lingkar leher } \\
\begin{array}{l}\geq 40 \mathrm{~cm}) \\
\text { Perokok }\end{array}\end{array}$ & 1,44 & $1,129-1,843$ & $0,005^{*}$ \\
Hipertensi & 1,35 & $1,155-1,713$ & $0,045^{*}$ \\
\hline
\end{tabular}

*Uji Regresi logistik; OSA: obstructive sleep apnea; FA: fibrilasi atrium; IK: interval kepercayaan.

Dilakukan analisis multivariat pada subjek risiko tinggi OSA dari variabel yang bermakna pada bivariat. Subjek dengan hipertensi mempunyai nilai PR paling tinggi $(2,42)$. Hal ini berarti hipertensi memiliki peluang kejadian yang paling besar untuk terjadinya risiko tinggi OSA, yaitu 2,42 kali lebih besar dibandingkan yang tidak hipertensi, dengan faktor usia, jenis kelamin, lingkar leher, dan merokok dikontrol (Tabel 3). Faktor lain yang memengaruhi risiko tinggi OSA adalah usia, jenis kelamin, lingkar leher, dan merokok.

Hasil analisis dari Tabel 4 menunjukkan bahwa nilai tolerance semua variabel $>0,1$ dan nilai VIF (variance inflation factor) semua variabel $<10$, maka dapat disimpulkan bahwa adanya independensi atau tidak ada multikolinieritas antar variabel independen.

Tabel 4. Uji Independensi Usia, Jenis Kelamin, Status Merokok, Lingkar Leher, dan Hipertensi dengan Risiko Tinggi OSA $(n=100)$

\begin{tabular}{lcc}
\hline \multicolumn{1}{c}{ Variabel } & VIF & Tolerance \\
\hline Kategori usia ( $>60$ Tahun) & 1,21 & 0,82 \\
Jenis kelamin (laki-laki) & 2,27 & 0,44 \\
Lingkar leher ( $\geq 40 \mathrm{~cm})$ & 1,24 & 0,81 \\
Perokok & 2,05 & 0,49 \\
Hipertensi & 1,24 & 0,81 \\
\hline Uji Indepedensi; OSA: obstructive sleep & apnea; FA: fibrilasi \\
atrium; VIF: variance inflation factor.
\end{tabular}

\section{PEMBAHASAN}

Penelitian ini menunjukkan sebesar 71\% pasien FA memiliki risiko tinggi OSA. Angka ini cukup tinggi dibandingkan dengan Porthan dkk yang mendapatkan prevalensi OSA $(\mathrm{AHI} \geq 15)$ pada pasien lone FA sebesar 32\%. ${ }^{6}$ Demikian pula Stevenson dkk memperoleh prevalensi OSA pada pasien FA sebesar $62 \%$, lebih tinggi dibandingkan dengan kelompok kontrol. Semua penelitian tersebut menggunakan polisomnografi (PSG) untuk mendiagnosis OSA, sedangkan penelitian ini menggunakan kuesioner STOPBANG untuk menentukan risiko tinggi OSA, sehingga nilai prevalensi risiko tinggi OSA menjadi lebih besar.

Penelitian ini menunjukkan adanya pengaruh usia tua terhadap risiko tinggi OSA. Sebanyak 90,6\% subjek berusia $\geq 60$ tahun memiliki risiko tinggi OSA dengan risiko 1,85 kali dibandingkan usia $<60$ tahun. Peppard dkk juga menemukan prevalensi OSA pada kelompok usia 50-70 tahun sebesar 17\% dibandingkan kelompok usia 30-49 tahun sebesar 10\%. ${ }^{24-25}$

Usia merupakan prediktor kuat terjadinya FA. Prevalensi FA meningkat menjadi $2 x$ lipat pada usia 
60 tahun. Prevalensi FA bervariasi pada populasi etnis yang berbeda, namun penelitian epidemiologi secara konsisten menunjukkan prevalensi FA meningkat seiring dengan meningkatnya usia. ${ }^{26-28}$ Kejadian FA terutama pada usia tua yang akan meningkatkan risiko terjadinya OSA.

Obstructive sleep apnea terjadi pada pasien FA usia tua karena proses fisiologis pada orang tua diantaranya tonus otot faring dan massa otot yang menurun pada saluran napas yang akan diganti oleh lemak dan menyebabkan perubahan struktur disekeliling faring yang menyempitkan jalan napas. Selain itu pada orang tua terjadi penurunan refleks saluran napas terhadap tekanan negatif. Hilangnya refleks ini dan tonus otot faring yang menurun menyebabkan orang tua lebih mudah mengalami kolaps faring, sehingga menyebabkan OSA pada pasien FA. ${ }^{29-30}$

Jenis kelamin merupakan prediktor kuat terjadinya FA setelah usia, yaitu laki-laki berisiko terjadi FA sebesar 1,5 kali lipat. Insidens FA lebih tinggi pada laki-laki dibandingkan pada perempuan setelah faktor usia dikontrol. ${ }^{26-27}$ Laki-laki cenderung mengalami FA yang berarti juga berisiko tinggi mengalami OSA, seperti halnya penelitian ini. Sebanyak $86 \%$ subjek laki-laki memiliki risiko tinggi OSA sebesar 1,44 kali dibandingkan perempuan.

Hal itu sesuai dengan Young dkk di Amerika yang mendapatkan prevalensi OSA pada laki-laki lebih tinggi dibandingkan perempuan, yaitu $4 \%$ vs 2\%. Sama halnya di Asia oleh Ip dkk di Hongkong, prevalensi OSA $2 \%$ pada perempuan dan $4 \%$ pada laki-laki. Hal ini menunjukkan adanya pengaruh hormon dan karena distribusi lemak pada laki-laki terutama pada tubuh bagian atas serta ukuran otot lebih besar dari perempuan. Lingkar leher dan volume jaringan lunak di sekitar leher laki-laki juga lebih besar dibandingkan perempuan yang mengakibatkan ukuran jalan napasnya menjadi lebih sempit dan berisiko OSA. ${ }^{14,24}$

Penelitian di Rotterdam menunjukkan perokok dan bekas perokok sama-sama berhubungan dengan kenaikan risiko FA, namun insidens FA meningkat 2 kali lipat pada perokok. Merokok berhubungan dengan rekurensi FA pada pasien yang telah menjalani ablasi. ${ }^{26-27}$
Merokok juga berpengaruh dengan risiko tinggi OSA pada pasien FA pada penelitian ini. Sebanyak $84,6 \%$ subjek yang merokok memiliki risiko tinggi OSA sebesar 1,35 kali dibandingkan yang tidak merokok. Hal ini sesuai dengan Kang dkk bahwa jumlah yang merokok pada kelompok OSA lebih tinggi daripada kelompok tidak OSA. ${ }^{31}$

Obstructive sleep apnea terjadi pada pasien FA yang merokok karena merokok menyebabkan iritasi, inflamasi kronis pada mukosa jalan napas yang menimbulkan hiperplasia seluler, edema mukosa, epitelium menebal, dan fungsi silia terganggu, sehingga mengubah fungsi mekanik jalan napas serta meningkatkan resistensi jalan napas yang akhirnya menyebabkan kolaps jalan napas selama tidur. ${ }^{17,24,32}$

Gami dkk mendapatkan obesitas menyebabkan risiko FA bermakna secara signifikan pada kelompok usia dewasa muda, sebaliknya pada kelompok usia tua ( $\geq 65$ tahun). ${ }^{13}$ Penderita obesitas juga berisiko mengalami OSA. Menurut Valencia dkk yang mendapatkan OSA sedang-berat sebesar $23 \%$ pada BMI $>30$ dan $33 \%$ pada BMI $>40$. Namun penelitian ini tidak mendapatkan risiko tinggi OSA pada subjek dengan obesitas, dapat disebabkan karena rendahnya subjek dengan obesitas (14\%). Selain itu, penelitian ini dilakukan pada ras Asia dan menggunakan kuesioner STOPBANG, berbeda dengan penelitian Valencia pada ras kaukasia dan menggunakan PSG. ${ }^{33}$ Walau demikian, penelitian kohort oleh Abumuammar dkk menunjukkan IMT tidak berpengaruh terhadap kejadian OSA. ${ }^{34}$

Ukuran lingkar leher, lingkar pinggang, serta rasio lingkar pinggang panggul digunakan untuk menilai obesitas sentral dan indeks massa tubuh untuk penilaian obesitas perifer. ${ }^{24-35}$ Obesitas dengan IMT $>30 \mathrm{~kg} / \mathrm{m}^{2}$ dapat mengubah volume dan bentuk anatomi, lidah dapat terangkat sehingga mengurangi volume saluran napas atas. Infiltrasi lemak pada saluran napas atas dan daerah parafaring melemaskan palatum, lidah, epiglotis dan dinding faring yang menyebabkan saluran napas atas menjadi kolaps dan atau menyempit. Selain itu, leptin merupakan hormon yang dilepaskan oleh jaringan adiposa yang meningkat kadarnya pada obesitas. Leptin mempunyai peranan dalam regulasi kemorefleks dan kontrol pernapasan..$^{24,36-37}$ 
Adanya pengaruh bermakna ukuran lingkar leher tidak normal $(\geq 40 \mathrm{~cm})$ dengan risiko tinggi OSA pada pasien FA juga telah dibuktikan penelitian ini. Subjek dengan lingkar leher $\geq 40 \mathrm{~cm}$ sebesar 93,8\% memiliki risiko tinggi OSA dan lingkar leher $\geq 40 \mathrm{~cm} 1,40$ kali berisiko terjadi risiko tinggi OSA dibandingkan usia $<60$ tahun, sesuai dengan penelitian kohort oleh Abumuammar dkk. ${ }^{34}$

Lingkar leher merupakan penanda obesitas tubuh bagian atas. Obesitas tubuh bagian atas merupakan faktor risiko yang lebih kuat dari pada IMT, hal ini menunjukkan bahwa lingkar leher merupakan prediktor yang lebih kuat untuk terjadinya OSA dibandingkan IMT. Obesitas memengaruhi kolapsnya saluran faring melalui dua mekanisme. ${ }^{29-30}$ Pertama, obesitas meningkatkan jaringan lunak di sekeliling faring. Ukuran lingkar leher menggambarkan banyaknya timbunan lemak di leher yang dapat menyempitkan saluran napas atas. ${ }^{33}$ Kedua, obesitas terutama obesitas sentral meningkatkan volume lemak viseral, menurunkan volume paru-paru. Kolapsnya dinding faring meningkat seiring menurun volume paru-paru. ${ }^{36}$

Hipertensi mempunyai pengaruh terhadap risiko tinggi OSA pada pasien FA, hal ini dapat dilihat dari subjek yang memiliki hipertensi sebesar 83,8\% memiliki risiko tinggi OSA $(\mathrm{p}<0,001)$ dan nilai $P R$ $(2,42)$ yang paling besar dibandingkan faktor-faktor lainnya yang diteliti. Hipertensi dan FA sangat berhubungan erat dan telah dibuktikan sejak lama. Pasien hipertensi berisiko terjadi FA sebesar 1,2-1,5 kali lipat. ${ }^{26-28}$ Sekitar 50\% pasien hipertensi memiliki OSA pada penelitian kohort 125 pasien di Brazil dan hipertensi berisiko 1,66 kali lipat menjadi OSA. ${ }^{16}$

Hipertensi dapat menyebabkan terjadinya OSA pada pasien FA melalui peranan renin angiotensin aldosteron system (RAAS) yang meningkat pada hipertensi kronis. Hal ini menyebabkan terjadinya retensi natrium, cairan, dan peningkatan permeabilitas membran vaskular akibatnya perpindahan cairan dari plasma ke ekstraseluler. Proses tersebut juga terjadi di leher, terjadi perpindahan cairan intravaskular ke jaringan di sekeliling leher yang menyebabkan tahanan pada saluran napas atas akan meningkat dan kolaps saluran napas. ${ }^{16}$
Penelitian ini memiliki kemungkinan bias karena hipertensi, usia tua, jenis kelamin laki-laki, lingkar leher, dan merokok dapat menyebabkan terjadinya OSA tidak hanya pada pasien FA, namun juga pada pasien tidak FA. Oleh karena itu perlu dilakukan penelitian lebih lanjut dengan rancang studi kasus kontrol pada kelompok pasien tidak FA. Pasien FA dengan hipertensi, usia tua, laki-laki, lingkar leher $\geq 40 \mathrm{~cm}$, dan merokok perlu dilakukan deteksi risiko tinggi OSA dan edukasi tentang OSA.

\section{KESIMPULAN}

Faktor-faktor yang berhubungan dengan risiko tinggi OSA pada pasien FA secara berurutan adalah hipertensi, usia, jenis kelamin, lingkar leher, dan merokok.

\section{DAFTAR PUSTAKA}

1. Tung P, Anter E. Atrial fibrillation and sleep apnea: considerations for a dual epidemic. J Atr Fibrillation. 2016;8(6):1283.

2. Cadby G, McArdle N, Briffa T, Hillman DR, Simpson L, Knuiman M, dkk. Severity of OSA is an independent predictor of incident atrial fibrillation hospitalization in a large sleep-clinic cohort. CHEST Journal. 2015;148(4):945-52.

3. Perki. Pedoman tata laksana fibrilasi atrium. Edisi ke1. Jakarta: Centra Communications; 2014. h. 11-24.

4. Fein AS, Shvilkin A, Shah D, Haffajee CI, Das S, Kumar K, dkk. Treatment of obstructive sleep apnea reduces the risk of atrial fibrillation recurrence after catheter ablation. J Am Coll Cardiol. 2013;62(4):300-5.

5. January CT, Wann LS, Alpert JS, Calkins H, Cigarroa JE, Cleveland JC, dkk. 2014 AHA/ACC/HRS guideline for the management of patients with atrial fibrillation. Circulation. 2014;130(23):199-267.

6. Maan A, Mansour M, Anter E, Patel VV, Cheng A, Refaat MM, dkk. Obstructive sleep apnea and atrial fibrillation: pathophysiology and implications for treatment. Crit Pathw Cardiol. 2015;14(2):81-5.

7. Stevenson IH, Teichtahl H, Cunnington D, Ciavarella S, Gordon I, Kalman JM. Prevalence of sleep disordered breathing in paroxysmal and persistent atrial fibrillation patients with normal left ventricular function. Eur Heart J. 2008;29(13):1662-9.

8. Zhang L, Hou Y, Po SS. Obstructive sleep apnoea and atrial fibrillation. Arrhythm Electrophysiol Rev. 2015;4(1):14-8.

9. Garrigue S, Border P, Jais P, Shah DC, Hocini M, Raherison C, dkk. Benefit of atrial pacing in sleep apnea syndrom. N Eng J Med. 2002;346(6):404-12

10. Morady F. Atrial fibrillation: clinical features, 
mechanism, and management. Edisi ke-9. Dalam: Bonow RO, Mann DL, Zipes DP, Libby P, editor. Braunwald's heart disease. A text book of cardiovascular medicine. Philadelphia: Elsevier Saunders; 2012. h. 25.

11. Latina JM, Estes Nr, Garlitski AC. The relationship between obstructive sleep apnea and atrial fibrillation: a complex interplay. Pulm Med. 2013.5(1):11-1.

12. Gunawan PY. Prevalensi risiko obstructive sleep apnea menggunakan kuesioner STOP-BANG dan hubungannya dengan faktor risiko stroke lain pada populasi normal. Neurona. 2013;30(4):1-9.

13. Gami AS, Hodge DO, Herges RM, Olson EJ, Nykodym J, Kara T, dkk. Obstructive sleep apnea, obesity, and the risk of incident atrial fibrillation. J A Coll Cardiol. 2007;49(5):565-71.

14. Tedjasukmana R. Obstructive sleep apnea syndrom. Edisi ke-1. Surabaya: Kelompok Studi Gangguan Tidur, PERDOSSI; 2014. h. 10-9.

15. Phillips CL, O’Driscoll DM. Hypertension and obstructive sleep apnea. Nat Sci Sleep. 2013;5:43.

16. Konecny T, Kara T, Somers VK. Obstructive sleep apnea and hypertension: an update. Hypertension. 2014;63(2):203-9.

17. Krishnan V, Dixon-Williams S, Thornton JD. Where there is smoke... there is sleep apnea: exploring the relationship between smoking and sleep apnea. Chest. 2014;146(6):1673-80.

18. Boynton G, Vahabzadeh A, Hammoud S, Ruzicka DL, Chervin RD. Validation of the STOP-BANG questionnaire among patients referred for suspected obstructive sleep apnea. J Sleep Disord Treat Care. 2013;2(4).

19. Perki. Pedoman tatalaksana hipertensi pada penyakit kardiovaskular. Edisi ke-1. Jakarta: Indonesian Heart Association. 2015. h. 1.

20. World Health Organization. Global database on body mass index; 2006.

21. Chung F, Abdullah HR, Liao P. STOP-BANG questionnaire: a practical approach to screen for obstructive sleep apnea. Chest. 2016;149(3):631-8.

22. WHO. Definition of an older or elderly person. WHO [serial online] 2013 [diunduh 31 Maret 2018]:4-1. Tersedia dari: SCRIBD.

23. NHIS. Adult tobacco use-glossary. CDC [serial online]. 2017 [diunduh 1 April 2017]:1. Tersedia dari: CDC.

24. Franklin KA, Lindberg E. Obstructive sleep apnea is a common disorder in the population - a review on the epidemiology of sleep apnea. J Thorac Dis.
2015;7(8):1311-2.

25. Peppard PE, Young T, Barnet JH, Palta M, Hagen EW, Hla KM. Increased prevalence of sleepdisordered breathing in adults. Am J Epidemiol. 2013;177(9):1006-14.

26. Andrade J, Khairy P, Dobrev D, Nattel S. The clinical profile and pathophysiology of atrial fibrillation. Circ Res. 2014;114(9):1453-68.

27. Staerk L, Sherer JA, Ko D, Benjamin EJ, Helm RH. Atrial fibrillation. Circulation Research. 2017;120(9):1501-17.

28. Voigt N, Heijman J, Wang Q, Chiang DY, Li N, Karck M, dkk. Cellular and molecular mechanisms of atrial arrhythmogenesis in patients with paroxysmal atrial fibrillation. Circulation. 2013; CirculationAHA-113:006641.

29. Eckert DJ, Younes MK. Arousal from sleep: implications for obstructive sleep apnea pathogenesis and treatment. J Appl Physiol. 2014;116(3):302-13.

30. Hsia JC. Anatomy and physiology of the upper airway in obstructive sleep apnea. Operative Techniques in Otolaryngology Journal. 2015;26(2):74-7.

31. Kang HH, Kang JY, Ha JH, Lee J, Kim SK, Moon HS, dkk. The associations between anthropometric indices and obstructive sleep apnea in a Korean population. PloS One. 2014;9(12):e114463.

32. Li Q, Zhou L, Lin Y. Smoking and OSA: a vicious cycle and synergistic effects. Austin Journal of Sleep Disord. 2015;3(2):1016.

33. Puja Kohli RS, Atul Malhotra. Management of sleep disordered breathing. Edisi ke-2. China: Lippincott Williams \& Wilkins; 2011. h. 19.

34. Abumuamar AM, Dorian P, Newman D, Shapiro CM. The prevalence of obstructive sleep apnea in patients with atrial fibrillation. Clin Cardiol. 2018;41(5):6017.

35. Chen X, Pensuksan WC, Lohsoonthorn V, Lertmaharit S, Gelaye B, Williams MA. Obstructive sleep apnea and multiple anthropometric indices of general obesity and abdominal obesity among young adults. Int J Soc Sci Stud. 2014;2(3):89.

36. Lailiyya N, Sobaryati, Miftahurachman, Marina. Hubungan neuropati otonom dan risiko obstructive sleep apnea syndrome pada pasien diabetes mellitus tipe 2. Neurona. 2017;3(3):137-44.

37. Sihite ACY, Nushrotul L, Uni G. Hubungan antara skor mallampati dan obesitas dengan risiko obstructive sleep apnea/hypopnea syndrome (OSAHS) pada anak down syndrome [tesis]. Bandung: Universitas Padjadjaran; 2017. 